\title{
Use of methods for decision-making support in anti-terrorism operations
}

\section{Introduction}

This article contains the results of a staff helping effort. It is an aid for decision-making and course of action (COA) comparison to staff which is incorporated at the planning and decision making process (DMP) at battalion and brigade level. This aide relies on a newly-proposed method. According to the results of the performed analysis there was a selected group of problem areas during DMP. Additionally analyzing the results from the questionnaire and according to these results, there were specified problem areas related to the phases of the DMP. According to this analysis the most vulnerable phase of DMP is Phase III - COA development/Analysis/Comparison, because it is highly influenced by the subjective evaluation of the evaluators. Another factor which influences DMP is the dissemination of the opinion of experienced officers to the less experienced. This influence differs according to military specialization but it is not always positive. From these results and contemporary valid methods, the authors of this article developed a method which will simplify DMP and also evade intuition and experienced officers' negative influence from it.

\section{New method to support DMP at the tactical level}

According to the results of the analysis, experts' opinions and assessment of the first part of the questionnaire found that in the near future there will probably be no change in the philosophy of the DMP at the tactical level. There is also no expectation that the structure of the DMP will be changed despite the fact that some 
phases will be developed or will incorporate newly developed DMP support methods. Based on the previous mentioned facts and authors' experience a problem was identified and inside that problem a need for a method which will simplify the DMP and focus staff officers on their specialized evaluation. Theanalysis showed that the knowledge of staff officers (based on their military specialization) is less used due to the lack of time, increased stress, or even due to the unsatisfactory specialized preparation of those staff officers. The space to use the proposed method was specified in the - COA comparison/approval phase of the DMP, which is one of its most important parts. Staff officers have to present their specialized, general, and tactical knowledge, and even knowledge of tactical norms during this phase.

This newly developed method is based on previously-used methods which were analyzed for their strengths and weaknesses. After further discussions with experts the author developed a new method which meets all the criteria to methodically evade all previously mentioned problem areas within the DMP. During the development of this method author performed and lead discussions with experts and staff officers within a wide spectrum of military specializations and in accordance with their lessons identified (or even learned) the author developed a specialized Microsoft Excel-based tool. This tool is fully developed to meet all criteria during DMP and is accessible only for specific staff officers during a specified time frame and specified parts only (functionality of this tool will be described later). The opinions, lessons identified and stated problems are named "Military specialization's questions" and the tool is based on them. The principle of this method is that during DMP when the COA comparison phase starts, all evaluators are focused on their part of this tool only and are also comparing COAs from their military specialization's perspective and therefore not influenced by unwanted factors.

Simplification of this process is based on a newly-developed method and MS Excel tool called "Matrix of criteria (MaC)". This tool will, in accordance with information flow (Picture 1), automatically evaluate points of each COA and will recommend the best one which is later proposed to the commander as the best. All evaluators are focused on their "Military specialization's questions" and also divided by different attitudes to their part of COA comparison. By applying this principle they are not influenced by other evaluators. "Military specialization's questions" were formulated by experts for each military specialization and are predefined as suitable for all military operations including Antiterrorism. Depending on the military specialization, the questions are the same or different for different types of military activity, but all of them focus the evaluators on their specialized knowledge and experience. The evaluator asks him/herself questions and answers these questions according to his/her knowledge and experience, so the expectation is that answers will be different for different types of military activities, and also there is a minor influence from other evaluators. Another strength of this method is that it focuses the evaluators onto their military specialization 
perspective and additionally it supports their specialized knowledge, even within time-limited environment. These questions are compiled by experts from the Slovakian Military Land Forces and also the Czech Army, and are fully-developed according to the lessons identified/learned from recent military operations.

The $\mathrm{MaC}$ method is based on the completion of a mathematical matrix which is based on the weighted decision support matrix. The main purpose of the $\mathrm{MaC}$ is to decrease the level of negative cross-influence of staff officers during DMP and also minimizes intuitional decisions, because it makes the evaluator focus on predefined questions based on their military specialization. The $\mathrm{MaC}$ tool is based on Microsoft Excel because it is standardized and used all over the world. The matrix itself is divided into 4 parts (each separate Excel sheet) and it is accessible only to specified staff members. The first part is the Executive officer/Chief of staff sheet which is accessible only for him/her. Secondly, there are the sheets of military advisors according to their specialization or function within the staff (G1, G2, G3, G4, G6, Artillery, Engineer, CBR or CBRN, GBAD, ALO, PSYOPS, CIMIC). The next part includes the matrix supporting functionality sheets but they are locked against changes and rewriting. The final part is the Executive officer/chief of staff evaluation sheet which is protected, because all results from all advisors/staff functions are automatically generated inside. It also automatically generates and proposes the best COA according to the results. $\mathrm{MaC}$ is fully functional according to the information flow (Picture 1).

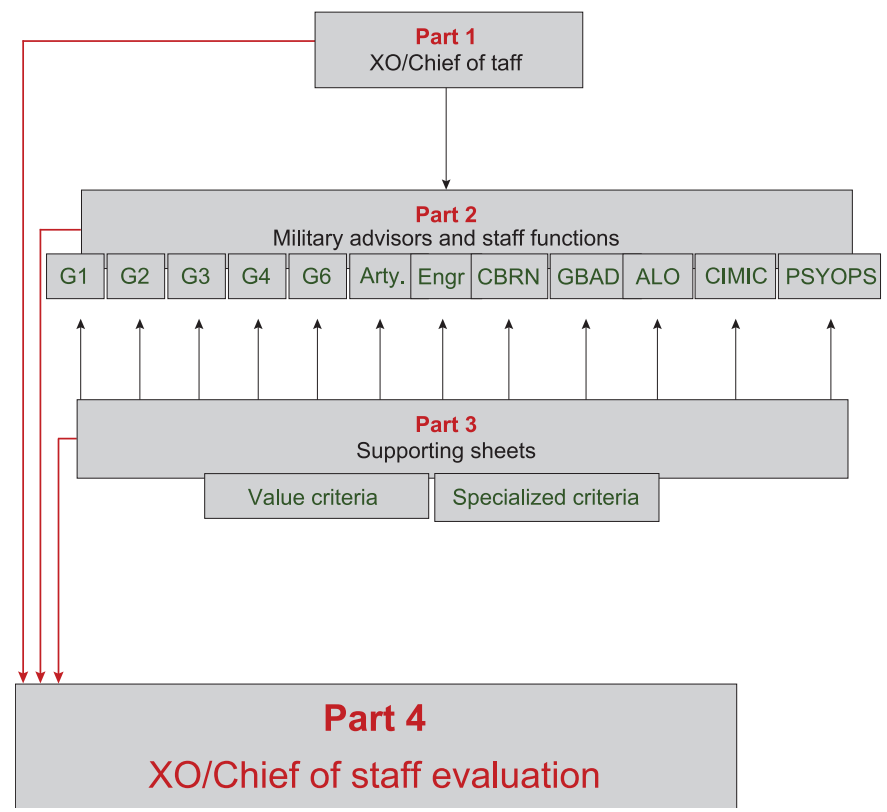

Picture 1. MaC information flow

Source: authors' design. 
The user/evaluator needs no special preparation to use MaC, only basic knowledge and skills with Microsoft Excel. Thework starts with choosing the evaluators in Part 1 - the $\mathrm{XO} / \mathrm{Chief}$ of staff sheet and basically choosing the type of military activity (Offense, Defense, etc.). The next step for the XO/Chief of staff is to choose 5 criteria from the criteria list and add to those criteria their weight (Picture 2). The criteria weight (sometimes also called importance coefficients) is a transformed numerical projection of the criteria which depends on the criteria importance in accordance with the plans' envisioned end state. Amore important criterion (evaluators' opinion) has a higher weight (value) and conversely a less important has a lower weight (value). The criteria list offers 16 of the most widely-used criteria from field manuals, doctrines and DMP supporting manuals. Here is the list of criteria:

1. Maneuver

2. Surprise

3. Fire support

4. INFOSEC/INTEL

5. Logistics

6. Simplicity

7. Coordination/C2

8. Timings

9. Signals and communications

10. Initiative

11. Economy of force

12. Reserves

13. Covering forces

14. Losses

15. Sustainability

16. Flexibility

The evaluator's (XO/Chief of staff) role is basically to choose the type of military activity in the first step and up to 5 criteria with weight in the next step. If the evaluator starts with choosing criteria without previously selecting a military activity tool he/she will be made aware of the following dialog window "Please choose military activity." Moreover, if the evaluator chooses more than one type of military activity tool he/she will also be made aware of the following dialog window "Please choose only one activity." Also, due to the simpler overview if the evaluator selects more than 5 criteria from the list he/she will be informed, because it makes DMP more complicated. After this, the evaluator's role is done. 


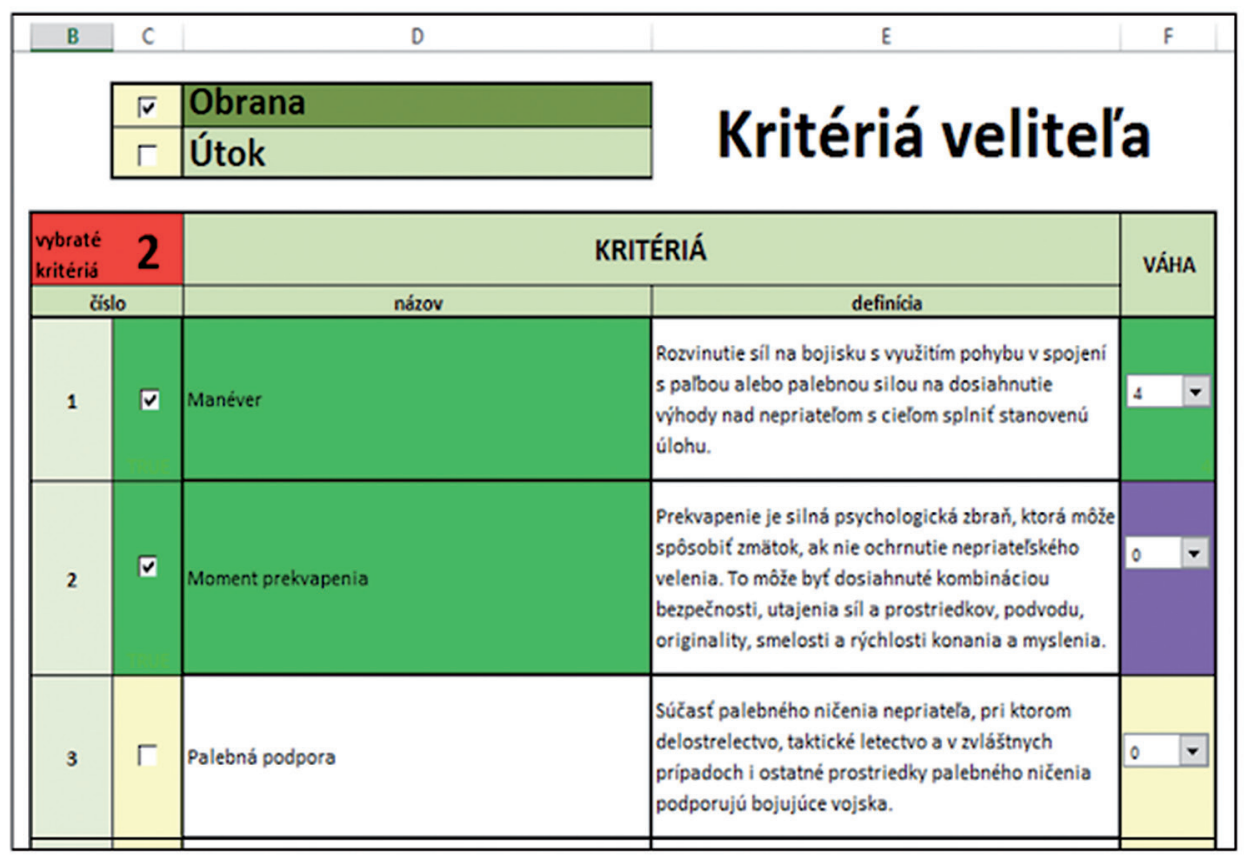

Picture 2. Example of the criteria and their weight choice within $\mathrm{MaC}$

Source: authors' design.

The next phase is based on the advisors and staff functions evaluation inside their own working sheets. The structure and functionality of these sheets is connected to Part 1 and they have already predefined criteria to evaluate including specialized questions to support the evaluation. For the choice the $\mathrm{MaC}$ author uses Microsoft Excel functions, for example: = IF (A4 = náčelník štábu'!\$H7; VALUE ('náčelník štábu'!I 7); IF (A4 = 'náčelník štábu'!H\$8; VALUE ('náčelník štábu'!I\$8); up to line 22).

The dvisor/staff function evaluators' role is to assign each COA with a value (scale is from 1 to 3 ) where more is better. Evaluation is automatically multiplied by weight and the result is generated. Each advisor/staff function assigns values according to the specialized questions, which decreases thelevel of external influence, cross-staff influence, and cross-specialization influence, and also minimizes emotional and intuitional influence on the evaluation.

The results are automatically generated to part 4 of the $\mathrm{MaC}-\mathrm{XO} / \mathrm{Chief}$ of staff evaluation sheet which is protected against rewriting by any user. There best COA is also generated according to the mathematical results from advisors/staff functions evaluations - the more computed points, the better the COA (Picture 4). 


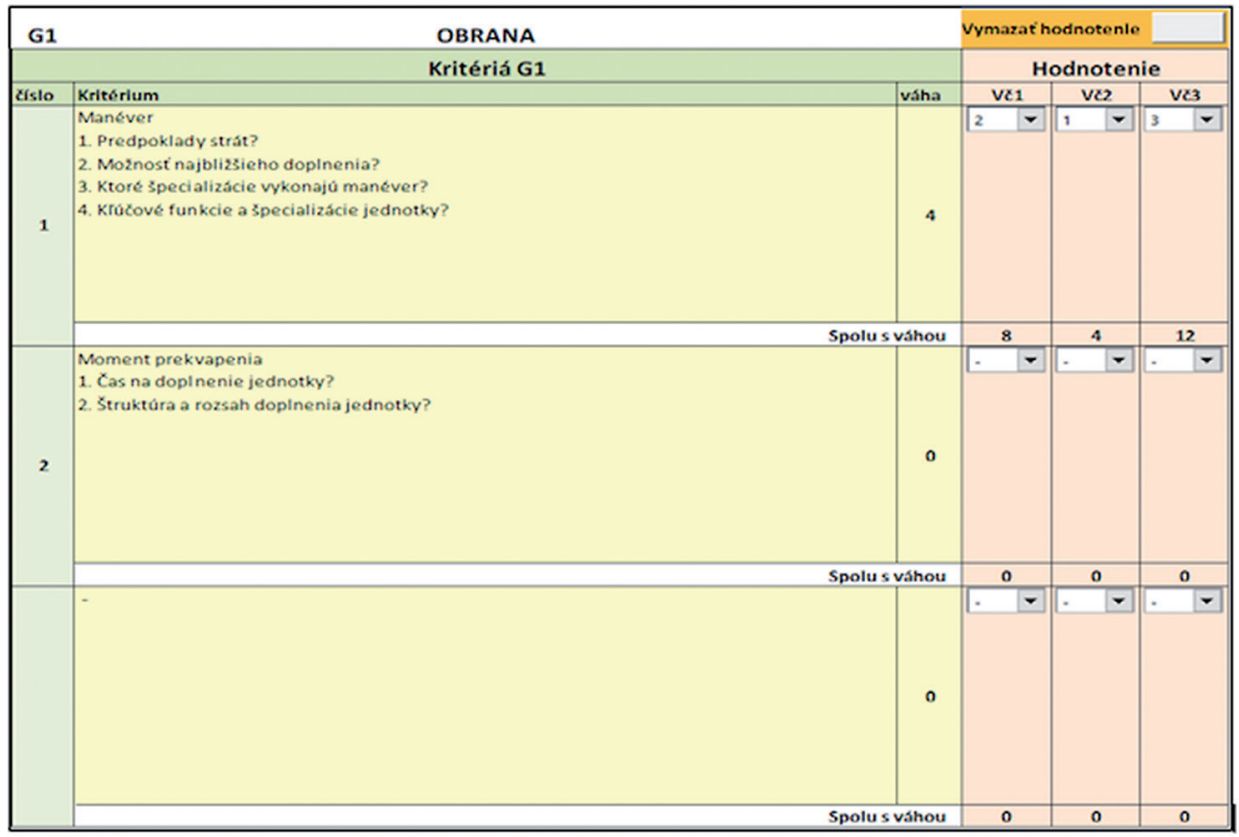

Picture 3. Sample sheet of a G1 staff officer

Source: authors' design.

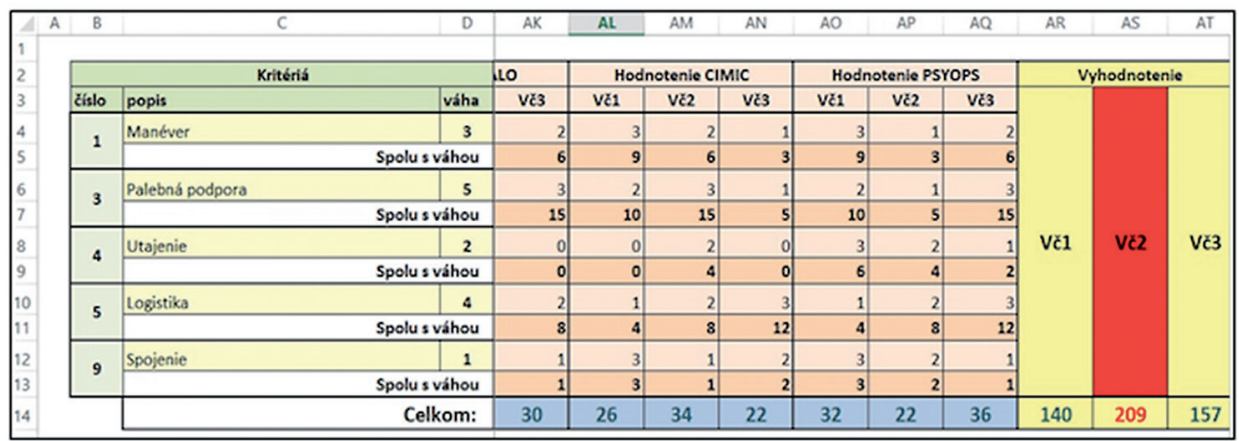

Picture 4. Sample XO/Chief of staff evaluation sheet - the best COA highlighted red Source: authors' design.

\section{Strengths and weaknesses of the $\mathrm{MaC}$ method}

One of the most advantageous points of this method is that it is an open source system which can be filled by additional criteria and specialized questions which means ongoing and never-ending improvement of the method. These methods are 
designed especially but not exclusively only for high intensity conflict activities, defense/offense but also after adding additional criteria and questions it is very reliable and supportive for the DMP during antiterrorist operations because it was developed to support DMP during crisis management. But the most important advantage of the $\mathrm{MaC}$ method is that it focuses evaluation of the advisors and staff functions onto their specialization and uses their specialized knowledge and experience, thereby shortening the process by using the computer-based tool.

The disadvantage of this method is seen within the framework of the more complicated operations including multiple missions and different military activities which apply partial solutions to each part/phase of the operation. In this case the $\mathrm{MaC}$ method must be applied to parts independently or criteria have to be reconstituted. Conversely, the advantage of using computers could cause major issues especially if affected by EW means.

But according to the analysis performed and also experts' opinion, $\mathrm{MaC}$ is one of the most suitable and time shortening methods to support DMP at the tactical level.

\section{Bibliography}

AAP-06, 2010. Terminologický slovník pojmů a definic NATO (anglicky a francouzsky), Úřad pro obrannou standardizaci, katalogizaci a státní ověrování jakosti, Odbor obranné standardizace. Praha.

AJP-5 - Allied Joint Doctrine For Operational Planning. NATO Standardization Agency. 2012, p. 174.

AFM - Army Field Manual, Vol. 1. Combined Arms Operations, part 8. Command And Staff Procedures.

Army Regulation HDv 100/100 Command and Control of Land Forces, Führungsstab des Heeres r. 2007, DSK HH320220020.

Birnstiel, M. et al. 2000. Wargaming. Germany: Bundeswehr Command and Staff College, p. 63. Comprehensive Operations Planning Directive. Allied Command Operations, Supreme Headquarters Allied Power Europe. 2013. Belgium, p. 444.

Doktrina armády České republiký. 2010. 2. Vydání, Praha: VGHMÚř Dobruška.

FM 6-0 The Operations Process. 2014. Washington DC.

Fort, J. et al. 2006. Manažérske rozhodováni: postupy, metody a nástroje. Praha: Ekopress, s.r.o.

Grasseová, M., Dubec, R., Řehák, D. 2010. Analýza v rukou manažera. 33 nejpouživanějšich metod strategického ř́zení. Brno: Computer Press, a.s., p. 326.

Grasseová, M., Mašlej, M., Brechta B. 2010. Manažerské rozhodování: Teoretická východiska a praktické př́klady. Brno: Univerzita obrany, p. 182.

Majtán, M., Dupaǐ, A. Manažment. 2003. Bratislava: SPRINT, p. 432.

Military Decision on MC 133/4, NATO Operations Planning, 24. November 2010.

Pub 53-01-1. 2006. Velení a řizení v operacích, Vojenská publikace. Vyškov: Vyškov: Ředitelství výcviku a doktrín, Správa doktrín.

Pub 53-01-2. 2007. Štábní práce v operacích, I. část, Mista velení a orgány, procesy a prostředky velení a řizeni. Vyškov: Ředitelství výcviku a doktrín, Správa doktrín. 
Služobná pomôcka: Metodika práce štábu brigády pri plánovaní operácií SPG-3-44/Oper., Velitel'stvo pozemných síl OS SR. 2012. Trenčín.

Služobná pomôcka: Metodika práce štábu práporu pri plánovaní operácií SPG-3-45/Oper., Velitel'stvo pozemných síl OS SR. 2011. Trenčín.

Služobná pomôcka: Vedenie operácií práporom SPG-3-14 B, Velitel'stvo pozemných síl OS SR. 2012. Trenčín.

Spilý, P., Hrnčiar, M. 2013. Vojenská taktika, Akadémia ozbrojených síl gen. M.R. Štefánika. Liptovský Mikuláš: AOS Liptovský Mikuláš.

Spišak, J. 2010. Komparační analýza rozhodovacího procesu velitele a štábu AČR s rozhodovacím procesem velitele a štábu zahraničnich ozbrojených sil. Brno: Univerzita Obrany Brno.

Vojenský terminologický slovník ozbrojených síl Slovenskej Republiky. 2008. Bratislava: Generálneho štábu ozbrojených síl Slovenskej Republiky.

Vojenský výkladový slovník vybraných operačních pojmu. 2004. Správa doktrín Ředitelství výcviku a doktrín. Praha: AVIS.

Wesselényi, J. 2014. Analýza a formulácia problému nevyuživania metód na podporu rozhodovania v procese plánovania operácií. Brno: Univerzita Obrany Brno.

\section{USE OF METHODS FOR DECISION-MAKING SUPPORT IN ANTI-TERRORISM OPERATIONS}

\section{Summary}

There are not any predefined common military planning processes of military antiterrorism operations at the tactical level within NATO member states. Each country defines its own planning and decision making processes mainly based on the allied publications AJP-5 and COPD. Despite the fact that each country phases the military planning process according to its own procedures and also names each phase differently, there is almost the same background philosophy. Strict definition combined with simpler phases (alternation of more complicated tasks with simpler tasks) of the military planning process within NATO member states will speed up the military planning process. This thesis describes the military planning process, its tools and common methods used during the decision making process with the main emphasis on the evaluation of the current status. The main goal of this thesis is to propose a new method for the Matrix of Criteria, its test by experiment and integration and incorporation into common military processes. Also, the goal of this thesis is to use this Matrix of Criteria during the military planning process, especially during the course of action comparison, evaluation, and approval step which will make this step simpler and also will focus the attention and the effort of each evaluator (staff officer) closer to their professional military branch.

Keywords: Planning and decision-making process, planning operations, decision-making, tactical level, management decision-making.

Jozef Wesselényi

jozef.wesselenyi@aos.sk

Jaroslav Kompan

jaroslav.kompan@aos.sk 